\title{
Koulurauhassa on kysymys motivaatiosta
}

\author{
Reijo Laukkanen, Pariisi
}

$\mathrm{K}^{\mathrm{o}}$ oulurauha on asia, josta on paljon puhuttu opettajanhuoneissa ja yleisönpalstoilla, mutta useinkaan sitä ei ole nostettu koulun kehittämisohjelmien fokukseen ennen kuin tilanne on kärjistynyt. On ehkä ajateltu, että työrauhaongelmat ovat yksittäisiä ja ohitse meneviä ja että niihin pitää puuttua vain paikallisin keinoin. Tämä on johtanut käsitykseen, että todella "paikallista" on, että asiat ratkaistaan mahdollisimman lähellä toimintaa, siis yksittäisessä koulussa. Suomessa koulujen ongelmia on ratkaistu käräjätupia myöten ja poliisin apuun luottaen. Tällöin on huomattu, että hierarkiassa mahdollisimman alhaalla oleva taso ei olekaan ainoa vastuullinen, vaan vastuuta on sälytetty myös ylemmäs. Perheilläkin on suuri vastuu.

$\mathrm{O}$ ngelmissamme emme ole yksin. Esimerkiksi Ranskan koulutoimi on suurissa vaikeuksissa. Tapaninpäivän 1999 myrskyn aiheuttamat fyysiset koulutuhot olivat suuret, mutta se edellyttää vain rahaa. Raskaammista ongelmista kertoo taas se, että kouluministeri Ségolène Royal on päättänyt jaetuttaa tyttöoppilaille katumuspillereitä, mikä katolisessa Ranskassa on melkoinen päätös. Koulujen väkivallasta lehdet ovat puhuneet pitkään.

Le nouvel Observateurin (14.1.1999) pääartikkeli osoitti, että väkivalta on nykypäivää sekä yläasteitamme vastaavissa että toisen asteen kouluissa. Ongelmat ovat suurimpia suurten kaupunkien vähemmän arvostettujen, usein siirtolaisten asuttamien, alueiden kouluissa. Lehdissä on puhuttu opettajien loppuunpalamisesta ja pitkistä sairaalajaksoista. Tilanne on mennyt opetus- ja tiedeministeri Claude Allègren mukaan niin pahaksi, että koulukurin palauttamisesta muodostuu nyt yksi opetustoimen prioriteeteista, mistä kirjoitti Le Monde (23.-24.1.2000 ja 27.1.2000). Hallituksen lupaaman toimenpideohjelman onnistumisesta kaikki eivät ole kovin vakuuttuneita. Le Figaro (25.1.2000) epäili sitä suuresti todeten, että hallitukset ovat tehneet jo aiemmin toimintaohjelmia tilanteen parantamiseksi, mutta työrauha on vain heikennyt.

Sekä Le nouvel Observateur että Le Monde esittivät numeroita. Sosiaaliselta taustaltaan "alhaalla" olevan Seine-Saint-Denisin alueella kaikesta kouluväkivallasta 69 prosenttia kohdistui ihmisiin. Siitä verbaalista väkivaltaa oli 25 , fyysistä 10, seksuaalista yksi ja muuta 33 prosenttiyksikköä. Muista koulurikkomuksista oli aseen hallussapitoa viisi, omaisuuden vahingoittamista kolme, varkauksia seitsemän ja poissaoloja 16 prosenttia. Suurimmat ongelmat ovat yläasteen kouluissa ja ammatillisissa lyseoissa. Pariisissa yläasteen kouluissa poissaolot muodostivat rikkomuksista 12 , kun taas toisen asteen oppilaitoksissa 60 prosenttia. Pinnaaminen on tuomittavaa, mutta vakavampaa on toiseen ihmiseen kohdistuva väkivalta. Kouluväkivalta kohdistuu pääasiassa oppilastovereihin, mutta myös opettajiin. Suurinta koulun henkilökuntaan kohdistuva väkivalta on ammatillisissa lyseoissa.

Libèrationin (24.1.2000) artikkeli "On occulte la violance scolaire" todistaa tutkimuksessa monesti nähdyn, että koulujen todellisuus piiloutuu ulkopuolisilta. Väkivaltaongelmat ovat pinnan alla, eivätkä oppilaat ole olleet halukkaita kertomaan niistä kenellekään. Mobbaus niellään itse itsemurhaan saakka. Vasta viimeaikoina asioita on alettu tuoda julki. 
$\mathrm{K}$ ouluviranomaiset varmasti voivat tehdä nyistä enemmän, mutta he eivät voi vahtia yksittäistä opetustilannetta. Kun OECD:n koulututkimuksen ja -innovaation keskus CERI:n hallintoneuvosto kävi keskustelun vuonna 1999 toteutettavasta "mikä toimii" -tutkimuksesta, kouluväkivalta nousi vahvasti esille. Usea maa olisi halunnut, että tutkimuksen teemana olisi ollut nimenomaan koulun työrauha. Tämä mielessä pitkän mielipidevaihdon jälkeen teemaksi valittiin "mikä toimii motivaatiossa". Keskeiseksi asiaksi nähtiin, että koulutyön pitää olla palkitsevaa, siis motivoivaa, minkä puutetta myös työrauhaongelmat heijastavat.

$\mathrm{K}$ oulurauhan ongelmien syyt ovat moninaia. Asioista ei puhuta niiden oikeilla nimillä. Ongelmia peitellään ja pidetään veran alla liian kauan. Ongelmia ei "nähdä" eikä tiedosteta. Pyritään vain ratkomaan esille tulleita yksittäistapauksia yrittämättä vaikuttaa ennaltaehkäisevästi koko opetuskulttuurin suuntaan. Työrauhaongelmien näkeminen motivaatio-ongelmiksi on unohdettu. Pitäisikö meilläkin julistaa opiskelumotivaation teemavuosi.

OECD:n motivaatioraportti julkistetaan kuluvan vuoden aikana. Tutkimus käsittelee kokemuksia useista maista. Maiden "motivaatiopolitiikkojen" yhteisenä piirteenä on yksilöllisyyden ja valintamahdollisuuksien kasvattaminen. Tapaustutkimuksista yksi on tehty Suomesta. Analyysi korostaa, että motivaation lisäämisessä on tehtävää hallinnon eri tasoilla. Jäämmekin odottelemaan analyysin tuloksia.

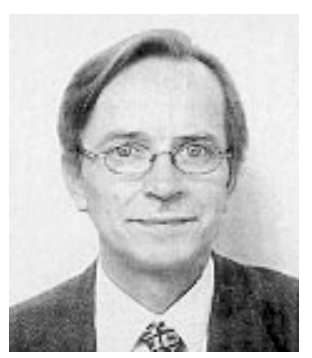

Reijo Laukkanen

$M$ iä tekemistä koulujen työrauhalla on aiuiskoulutuksen kanssa? Paljonkin. Tämän päivän koululaiset ovat aivan kohta huomisen aikuisia. Työrauhan heikkeneminen kertoo myös siitä, että koulusaavutukset todennäköisesti heikkenevät entisestään. Työelämässä ei kuitenkaan ole tilaa puutteellisia taitoja omaaville. Aikuiskoulutus saa tästä aivan uuden haasteen. Toinen yhtymäkohta on siinä, että erityisesti vapaan sivistystyön sektorin olisi syytä aktivoitua auttamaan avuttomia vanhempia. Skiniongelma ei ole vain yhteiskunnan murhe, vaan vanhempien suuri suru. Kolmas yhtymäkohta on, että elinikäinen oppiminen perustuu nimenomaan kykyyn ja haluun oppia uutta. Vaikka aikuiskoulutukseen houkutellaan, siihen osallistumisen keskeisin voima on oma pyrkimys itsensä kehittämiseen. Sen toteaa myös tänä vuonna ilmestyvä OECD:n raportti "How Adults Learn". Samasta narusta koulujenkin opettajien pitäisi oppia vetämään.

30.1 .2000

Erityisasiantuntija Reijo Laukkanen Suomen pysyvästä OECD-edustajistosta Pariisissa kommentoi Ranskan ja OECD:n ajankohtaisia koulutuspoliittisia kyskymyksiä Aikuiskasvatuksen eri numeroissa. 